\title{
Effects of job rotation and role stress among nurses on job satisfaction and organizational commitment Wen-Hsien $\mathrm{Ho}^{\dagger 1}$, Ching Sheng Chang*†1, Ying-Ling Shih*2 and Rong- Da Liang 3
}

Address: ${ }^{1}$ Dept. of Medical Information Management, College of Health Science, Kaohsiung Medical University, 100, Shih-Chuan 1st Road, Kaohsiung, 80708, Taiwan, ${ }^{2}$ Dept. of Nursing \& Nutrition Support Team, Kaohsiung Medical University Hospital, 100, Shih-Chuan 1st Road, Kaohsiung, 80708, Taiwan and ${ }^{3}$ Dept. of Marketing and Logistics Management, National Penghu University, Taiwan

Email: Wen-Hsien Ho - whho@cc.kmu.edu.tw; Ching Sheng Chang* - arthur0660@yahoo.com.tw; Ying-Ling Shih* - ylshih@cc.kmu.edu.tw; Rong-Da Liang - austra07@yahoo.com.tw

* Corresponding authors †Equal contributors

Published: 12 January 2009

BMC Health Services Research 2009, 9:8 doi:10.1186/1472-6963-9-8

This article is available from: http://www.biomedcentral.com//472-6963/9/8

(c) 2009 Ho et al; licensee BioMed Central Ltd.

This is an Open Access article distributed under the terms of the Creative Commons Attribution License (http://creativecommons.org/licenses/by/2.0), which permits unrestricted use, distribution, and reproduction in any medium, provided the original work is properly cited.

\begin{abstract}
Background: The motivation for this study was to investigate how role stress among nurses could affect their job satisfaction and organizational commitment, and whether the job rotation system might encourage nurses to understand, relate to and share the vision of the organization, consequently increasing their job satisfaction and stimulating them to willingly remain in their jobs and commit themselves to the organization. Despite the fact that there have been plenty of studies on job satisfaction, none was specifically addressed to integrate the relational model of job rotation, role stress, job satisfaction, and organizational commitment among nurses.
\end{abstract}

Methods: With top managerial hospital administration's consent, questionnaires were only distributed to those nurses who had had job rotation experience. 650 copies of the questionnaire in two large and influential hospitals in southern Taiwan were distributed, among which 532 valid copies were retrieved with a response rate of $81.8 \%$. Finally, the SPSS I I.0 and LISREL 8.54 (Linear Structural Relationship Model) statistical software packages were used for data analysis and processing.

Results: According to the nurses' views, the findings are as follows: (I) job rotation among nurses could have an effect on their job satisfaction; (2) job rotation could have an effect on organizational commitment; (3) job satisfaction could have a positive effect on organizational commitment; (4) role stress among nurses could have a negative effect on their job satisfaction; and (5) role stress could have a negative effect on their organizational commitment.

Conclusion: As a practical and excellent strategy for manpower utilization, a hospital could promote the benefits of job rotation to both individuals and the hospital while implementing job rotation periodically and fairly. And when a medical organization attempts to enhance nurses' commitment to the organization, the findings suggest that reduction of role ambiguity in role stress has the best effect on enhancing nurses' organizational commitment. The ultimate goal is to increase nurses' job satisfaction and encourage them to stay in their career. This would avoid the vicious circle of high turnover, which is wasteful of the organization's valuable human resources. 


\section{Background}

Job rotation inspires nurses to achieve higher performance, allowing continuous growth at work, extended knowledge and skill, and increasing clinic patient caretaking quality. Scholars have all proposed that job rotation may help employees to acquire multiple capabilities and expand vision, and that it can be an approach to reduce job burnout [1-3]. But emotional pressure often occurs in the work environment where interpersonal interactions are highly involved [4-6]. Especially, the nurses working at hospitals not only implement independent and professional nursing activities in accordance with doctors' advice, but take responsibility for any immediate threat to patients' lives as well. Thus, the importance of nurses is undeniable, and the influence of nurses' qualities and capabilities on medical care quality can never be ignored $[7,8]$. Therefore, the primary concern of the practical field of medical care is to exhaustively recognize how role stress among nurses could affect their job satisfaction and organizational commitment, and effectively utilize the job rotation system to enhance and develop nurses' job satisfaction and organizational commitment, in order to promote competitive advantages.

\section{Literature Review and Research Hypotheses Job rotation}

Job rotation is also called cross-training, meaning an employee of a unit or department can learn diversified job skills during a specific period of time; it is also regarded as a practical approach to enrich and expand job assignments [9]. Therefore, job rotation is also planned on-thejob training for cultivating future candidates of management by transferring a management trainee from one department to another to increase his or her understanding and credentials in all aspects [3]. In addition, job rotation is also regarded as a method of job design that, on top of allowing employees to learn job skills from different departments, eliminates employee fatigue caused by tedious job assignments by changing such assignments; the challenge of these new assignments can encourage an employee's enthusiasm once again, and improve employee morale to increase output $[10,11]$. When implementing job rotation, the quality of an individual's work experience should be focused on, instead of quantity. Organizations should arrange the next rotation plan according to each employee's learning capability and adjustment time [12]. Therefore, high frequency of job rotation may not be better; factors such as employee's background, learning status, and job familiarity should be taken into consideration for frequency of job rotation.

The definition of job rotation here refers to a professional job cross training plan that helps employees expand their job territory while broadening their working experience and skills, stimulating their working spirit and cultivating their interpersonal relationships by shifting medical personnel to different departments or units of the same department. In reality, job rotation means neither job promotion nor paid adjustment. The structure of this study was based on one rotation as the only variable. The task was mainly to obtain the opinions and inclinations of nursing personnel toward job rotation. The purpose is to discuss hospital nursing personnel's comments and opinions on the implementation of job rotation.

\section{Role stress}

$[4,5]$ suggested that a role is the manifestation of behavior appropriate to an individual's position. In an organization, an individual's role stress refers to "the stress formed by the combined expectations of an individual's behavior from all circles." While facing role stress, an individual may produce unfavorable behavior to an organization, such as performance reduction, job burnout, and resignation, which deserve to be taken seriously. In the role theory, [13] divided role stress into two types: role conflict and role ambiguity. [14] further separated "role overload" from role conflict, so that there are three types of role stress, which are role ambiguity, role conflict, and role overload [15]. [16], on the other hand, asserted that role stress is composed of five constructs, including role ambiguity, role overload, role conflict, role incongruity, and role incompetence or role over-qualification. This study adopts the viewpoint of role ambiguity, role conflict, and role overload as the three types of role stress.

\section{Job satisfaction}

[17] believed job satisfaction is a positive or negative attitude that an employee has toward his or her job or some specific aspects of the job, and is an internal state of mind of an individual. [18] pointed out it is a feeling or affection held by a member of an occupation system; if the feeling is positive or the response is active, then the member is satisfied, and vice versa. [19] proposed that job satisfaction is an employee's feeling about his or her work environment, which includes the job itself, supervisor, work group, organization, and life. $[20,21]$ suggested that the level of job satisfaction depends on the difference between what a person actually gains from his or her job and what he or she expects. [22] proposed that job satisfaction is the level in which an employee likes or dislikes his or her job. [23] also pointed out that job satisfaction is an employee's feeling about his or her job and is a general attitude derived from an evaluation of all aspects in a job.

\section{Organizational commitment}

$[24,25]$ indicated that organizational commitment is an individual's willingness to dedicate efforts and loyalty to an organization. The commitment to a job is because an individual believes the cost of leaving an organization is 
so high, that it is difficult for the individual to leave after consideration of the investment and sacrifice made to the organization [26,27]. Psychological commitment proposed by [28] is also called normative commitment. [29] explained that this type of organizational commitment means the members of an organization have active and highly positive inclination toward the organization, and such inclination includes identification with an organization's goals and values, dedication to a job, and loyalty to an organization. [30,31] described the process of the forming of organizational commitment with investment and dedication that an individual shall develop a relatively deep identification with an organization after such individual has invested in the organization at a relatively high level, and a forced commitment to the organization is consequently formed. [32,33] pointed out that basically organizational commitment is a structural phenomenon of a transaction between an individual and an organization, and its non-transferable investment result shall increase as time goes on; members are reluctant to leave the organization because of the salary, status, position, and friendship among colleagues.

\section{Relationships among job rotation, job satisfaction, and organizational commitment}

In regard to the relationship between job satisfaction and organizational commitment, [34-36] pointed out in their study of job satisfaction and organizational commitment that the two have significant positive correlation $[37,38]$. $[10,39,19]$ proposed that job rotation has the advantage of increasing job satisfaction. [12,40] also believed implementing job rotation has the advantage of increasing organizational commitment in the aspect of employees' career and emotion. From the above statements, the following hypotheses are formed:

Hypothesis 1: Nurses' job rotation has a positive influence on job satisfaction.

Hypothesis 2: Nurses' job rotation has a positive influence on organizational commitment.

Hypothesis 3: Nurses' job satisfaction has a positive influence on organizational commitment.

\section{Relationships among role stress, job satisfaction, and organizational commitment}

The results of the research of [24,41] showed that there is a significant negative correlation between role stress and organizational commitment, and role conflict, role ambiguity, and role overload have the most remarkable influence in the construct of role stress $[42,5]$. In regard to the relationship between role stress and job satisfaction, $[15,5]$ found that the tension at work caused by role ambiguity, role conflict, and role overload has a significant neg- ative correlation with job satisfaction. From the above statement, the following hypotheses are formed:

Hypothesis 4: Nurses' role stress has a negative influence on job satisfaction.

Hypothesis 5: Nurses' role stress has a negative influence on organizational commitment.

\section{Methods}

\section{Research Framework (Model)}

Our conclusion from the motivation, purpose, and literature review is that nurses' job rotation has a positive influence on job satisfaction and organizational commitment, nurses' job satisfaction has a positive influence on organizational commitment, and role stress among nurses has a negative influence on their job satisfaction and organizational commitment. Therefore, in this study, job rotation and role stress among nurses are independent variables, and organizational commitment is a dependent variable, while job satisfaction is the mediating variable, in order to discuss the correlation among all the variables. The overall research framework is shown as Figure 1.

\section{Research Subject and Sampling Method}

There are two reasons for the job rotation of nurses: 1 . The planned rotation: for example, in compliance with the promotion of nurses in basic units or training of associate head nurses; 2. Non-planned rotation: for instance, largescale temporary transfer of personnel to different sections and offices in a unit (due to support for other units, dismissal, leave of absence and so on). Generally, the period for the first type of rotation is a half year and for the second type is about three months.

In order to survey a diverse and representative sample of RNs, nursing staff in two large and influential hospitals (each was a teaching hospital and medical center, and each had more than 1200 sickbeds) in southern Taiwan were surveyed. We first visited the management supervisors at the hospitals in person to acquire approval. Volunteer supervisors of nurses were asked to post on bulletin boards at their respective units a notice for recruiting volunteer nurses who would participate in the anonymous questionnaire. The response period was limited to two months. A seminar was delivered to the supervisors of the nurses to explain the details, and an introductory letter was attached to the questionnaire to explain the motivation of this study and guarantee the respondents' confidentiality. Anyone who was also interested in learning about the result of this study was able to request a copy through the contact address provided in the questionnaire. 650 copies of the questionnaire were only distributed (Medical Center A: 340 copies; Medical Center B: 310 copies) to those nurses who had had job rotation experi- 


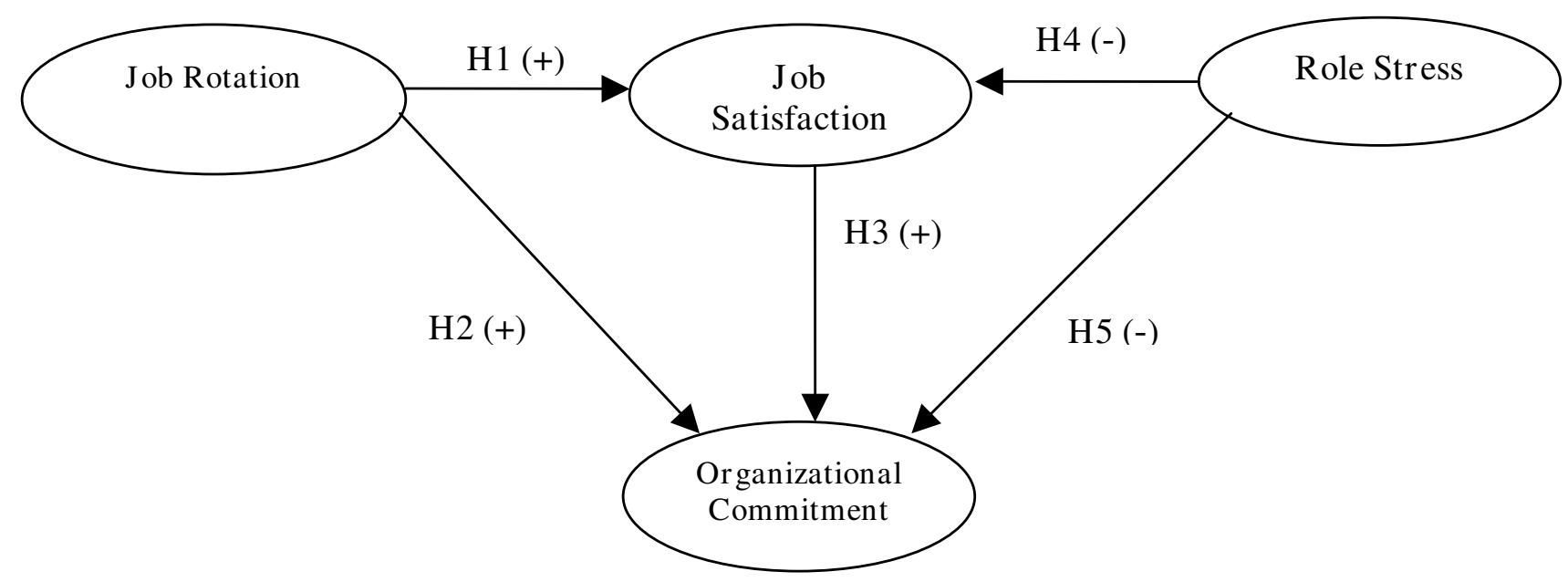

Figure I

Conceptual framework of the relationship among job rotation, job satisfaction, organizational commitment, and role stress.

ence, and 550 were collected between October 2006 and December 2006, among which 18 were rejected due to incomplete answers. 532 valid copies were collected (Medical Center A: 273 copies; Medical Center B: 259 copies), and the valid response rate was $81.8 \%$.

\section{Study Tools}

The following is the explanation of the questionnaire which comprised questions already developed in foreign studies and modified to serve the study purposes. First, dimensions of questionnaire forms were obtained from the literature and used to compile questionnaires. Second, the dimensions were slightly modified to create initial questionnaires based on the research purposes and industry features. Third, tests were repeatedly administered to three academic professors in the industry, and to two medical specialists and five nurses with experience of job rotation; a pilot run of the questionnaire was administered to 38 nurses. Thirty-two valid questionnaire forms meeting the acceptable standard of more than thirty recommended by [43] were collected, and the analytical results indicated that all factor loadings were greater than 0.7, and all Cronbach's $\alpha$ values exceeded 0.7, therefore, none of the items were deleted [43]. Finally, the questionnaire was officially released. Deserving of special attention is that, the questionnaire employed did not allow the measurement of job rotation levels, and thus, cannot establish whether participants experienced job rotation or not.

The questionnaire employed a 5-point Likert scale from 1, for "strongly disagree" to 5, for "strongly agree." Table 1 summarizes constructs and variables, including operational definitions for all variables. Questionnaires were examined for reliability and validity as follows:
1. Reliability analysis: Principal component factor analysis was used to extract major contributing factors, and varimax of the orthogonal rotation was performed to maximize the differences in factor loading carried by every common factor after the rotation to help recognize common factors. Thus, as Table 2 illustrates, the analytical results indicated that factor loadings were 0.79 to 0.92 meeting the acceptable standard of more than 0.7 , and all Cronbach's $\alpha$ values exceeded $0.7[43,44]$.

2. Construct convergent validity (confirmatory factor analysis): The confirmatory factor analysis could gain higher recognition than expert content validity [43], and the results for all dimensions were listed in Table 3 . All of the adequacy indicators met the acceptable standard recommended by [43]. Parameter $(\lambda)$ between each latent variable and manifest variable were estimated to determine the significance of the estimated parameter $(\lambda)$ in order to evaluate convergent validity. Thus, as Table 4 shows, the $t$ values for the factor loading of all measurement items reached the level of significance $(p<0.01)$, no single factor included only one question, and the composite reliability values for all constructs were greater than 0.6 , which demonstrated satisfactory convergent validity $[45,43]$.

\section{Data Analysis Method}

Finally, the SPSS 11.0 and LISREL 8.54 (Linear Structural Relationship Model) statistical software packages were used for data analysis and processing, as follows:

1. Descriptive statistical analysis: To see the characteristics of samples. 
Table I: Summary of Constructs and Variables

\begin{tabular}{|c|c|c|c|}
\hline Construct & Variable & Operational Definition & References \\
\hline Job Rotation & Job Rotation & $\begin{array}{l}\text { Hospital nursing personnel transfer among } \\
\text { departments of different functions or different units of } \\
\text { the same department without promotion or salary } \\
\text { adjustment. }\end{array}$ & $\begin{array}{l}\text { Campion et al. (1994) \& Anil and Brian } \\
(2004)\end{array}$ \\
\hline \multirow[t]{3}{*}{ Role Stress } & Role Ambiguity & $\begin{array}{l}\text { Insufficient information about work objectives to be } \\
\text { completed and the uncertainty of others' expectations } \\
\text { toward an individual and the results generated after } \\
\text { objectives have been accomplished. }\end{array}$ & $\begin{array}{l}\text { Kahn et al. (1964), Piko (2006), \& Van } \\
\text { Sell, Brief, and Schuler (198I) }\end{array}$ \\
\hline & Role Conflict & $\begin{array}{l}\text { Under the conditions of an individual's time, resources, } \\
\text { capability, or value, it (role conflict) may take place if } \\
\text { the conditions are inconsistent with the standards, } \\
\text { criteria, and expectations set by role senders. }\end{array}$ & \\
\hline & Role Overload & $\begin{array}{l}\text { Psychological burden that is formed when a role } \\
\text { sender has overly high requirement and expectations } \\
\text { for a role recipient's job, which exceeds what the role } \\
\text { recipient is capable of, from a legitimated position. }\end{array}$ & \\
\hline \multirow[t]{2}{*}{ Job Satisfaction } & Internal Satisfaction & $\begin{array}{l}\text { The opportunities to demonstrate abilities, sense of } \\
\text { achievement obtained from work, ethical values of the } \\
\text { work, opportunities to provide services. }\end{array}$ & $\begin{array}{l}\text { Judge and Bono (200I) \& Best and } \\
\text { Thurston (2004) }\end{array}$ \\
\hline & External Satisfaction & $\begin{array}{l}\text { Job content, salary, unobstructed channels for } \\
\text { promotion, work environment and equipment. }\end{array}$ & \\
\hline \multirow[t]{3}{*}{$\begin{array}{l}\text { Organizational } \\
\text { Commitment }\end{array}$} & Value Commitment & $\begin{array}{l}\text { Strong beliefs in and acceptance of the organizational } \\
\text { objectives and values. }\end{array}$ & Porter et al. (1974) \& Trimble (2006) \\
\hline & Effort Commitment & $\begin{array}{l}\text { Willingness to dedicate more efforts for the } \\
\text { organizational benefits. }\end{array}$ & \\
\hline & Retention Commitment & $\begin{array}{l}\text { Willingness to stay in the organization as a member of } \\
\text { the organization. }\end{array}$ & \\
\hline
\end{tabular}

2. Structural Equation Modeling (SEM): According to [46], structural equation modeling allows not only the determination of relationship extent between variables, but also the examination of chain of cause and effect. This means that results do not merely show empirical relationships between variables when defining the practical situation. For this reason, this study chose structural equation modeling to test hypotheses. This study also used several indices, including Chi-square ratio $(<3)$, goodness of fit index (GFI > .9), adjusted goodness of fit index (AGFI > $.8)$, normal fit index (NFI $>.9)$ and root mean square of standardized residual (RMSR $<.08)$ to evaluate overall model fitness.

Table 2: Results of Reliability Analyses

\begin{tabular}{|c|c|c|}
\hline Construct & Factor Naming & Cronbach's $\alpha$ \\
\hline \multicolumn{3}{|l|}{ Job rotation } \\
\hline & Job rotation & 0.92 \\
\hline \multicolumn{3}{|l|}{ Role Stress } \\
\hline & Role Ambiguity & 0.79 \\
\hline & Role Conflict & 0.82 \\
\hline & Role Overload & 0.81 \\
\hline \multicolumn{3}{|c|}{ Job Satisfaction } \\
\hline & Internal Satisfaction & 0.88 \\
\hline & External Satisfaction & 0.89 \\
\hline \multicolumn{3}{|c|}{ Organizational Commitment } \\
\hline & Value Commitment & 0.82 \\
\hline & Effort Commitment & 0.88 \\
\hline & Retention Commitment & 0.85 \\
\hline
\end{tabular}


Table 3: Results of Convergent Validity Analysis

\begin{tabular}{ccccc}
\hline Indicator & Job Rotation & Role Stress & Job Satisfaction & Organizational Commitment \\
\hline$\chi 2 /$ df. $(<3)$ & 2.96 & 2.47 & 2.55 & 2.30 \\
GFI $(>.9)$ & 0.90 & 0.93 & 0.91 & 0.93 \\
AGFI $(>.8)$ & 0.82 & 0.87 & 0.83 & 0.85 \\
NFI $(>.9)$ & 0.91 & 0.90 & 0.91 & 0.93 \\
RMSR $(<.08)$ & 0.03 & 0.02 & 0.03 & 0.02 \\
\hline
\end{tabular}

Note. $\chi^{2} / \mathrm{df} .=$ Ratio of Chi-square, GFI = Goodness of Fit Index, AGFI = Adjusted GFI, NFI = Normal Fit Index, RMSR = Root Mean Square of Standardized Residual.

\section{Ethical Considerations}

The study had been verbally approved by each institution's ethics committee before the research started and before the supervisors were approached. Nursing staff supervisors were asked to post a notice requesting volunteers for the anonymous questionnaire on bulletin boards at their respective units. The nurse supervisor made the questionnaires available for volunteer nurses to fill out anonymously on site; respondent nurses could ask questions directly to the supervisor, and the supervisors collected even those questionnaires not filled out on site. The response period was limited to two months. The authors invited all nursing supervisors to a seminar to explain the details of the study, and an introduction letter was attached to the questionnaire to explain the purpose of the study and to ensure respondent confidentiality. The questionnaire provided contact information so that respondents could later inquire about the results of the study.

\section{Results}

\section{Characteristics of Samples}

The demographic data revealed that $48.1 \%$ of participants were under 30, and $57.7 \%$ were unmarried. Subjects with less than junior college education comprised $44.2 \%$ of the study population. The employment data revealed that $30.3 \%$ had between three and six years of work experience. $93.8 \%$ were not currently in management positions and $50.8 \%$ were currently working in hospital wards (see Table 5).

\section{The Relationships among Nurses' Job Rotation, Role} Stress, Job Satisfaction, and Organizational Commitment The Linear Structural Relationship Model was employed to examine the relationships among nurses' job rotation, role stress, job satisfaction, and organizational commitment $[45,46]$. Hypotheses 1 to 5 in this study were demonstrated to be significant, as in Figure 2. Nurses' job rotation had a positive influence on job satisfaction $\left(\gamma_{11}=\right.$ $0.51)$ and organizational commitment $\left(\gamma_{21}=0.46\right)$. Nurses' job satisfaction $\left(\beta_{21}=0.63\right)$ had a positive influence on organizational commitment. Nurses' role stress had a negative influence on job satisfaction $\left(\gamma_{12}=-0.52\right)$ and organizational commitment $\left(\gamma_{22}=-0.79\right)$. Figure 2 shows the SEM of this study and Table 6 shows the model fit goodness of the structural equation modeling. In short, it can be concluded that the research model is applicable for the data.

\section{Discussion \\ Conclusions and implications}

According to the nurses' views, there are five major results in this study: (1) job rotation among nurses could have an effect on their job satisfaction; (2) job rotation could have an effect on organizational commitment; (3) job satisfaction could have a positive effect on organizational commitment; (4) role stress among nurses could have a negative effect on their job satisfaction; and (5) role stress could have a negative effect on their organizational commitment. The implications are discussed, as follows:

\section{Academic implications}

Cases in which past researchers' viewpoints corresponded to the results of this study that job satisfaction has positive effects on nurses' organizational commitment [34,37]. Our findings also support the statement that job rotation could have an effect on nurses' job satisfaction and organizational commitment. This agrees with the assertions of previous relevant studies [12,40].

The results support that role stress exercises obviously negative influences on organizational commitment, this inference is in accordance with the assertions of certain scholars in the past $[47,48,5]$. The findings of this study also reveal that role stress exercises obviously negative influences on job satisfaction indicating that role stress among nurses negatively influences their job satisfaction. It is in accordance with the assertions of relevant studies in the past [49-51].

\section{Practical implications}

Due to the fact that hospitals depend on nurses' work to operate and it takes tremendous time and effort to train nurses' talent, retaining excellent nurses and stimulating them to do their best to serve hospitals and take on future challenges are crucial issues for hospitals to stay competitive in today's environment. As a practical and excellent strategy for manpower utilization, a hospital could pro- 
Table 4: Confirmatory Factor Analysis of all the Constructs

\begin{tabular}{|c|c|c|c|c|c|}
\hline Construct & Variable/Question Item & $\begin{array}{l}\text { Standardized } \\
\text { Loading }\end{array}$ & $\begin{array}{l}\text { Measurement } \\
\text { Error }\end{array}$ & $\begin{array}{l}\text { Composite } \\
\text { Reliability }\end{array}$ & AVE \\
\hline \multirow[t]{6}{*}{ Job Rotation } & I. I believe job rotation is a type of job training. (JRT) & $0.40 * *$ & 0.84 & 0.75 & 0.73 \\
\hline & $\begin{array}{l}\text { 2. Job rotation broadens my knowledge and skill in other fields. } \\
\text { (JRK) }\end{array}$ & $0.66 * *$ & 0.56 & & \\
\hline & 3. I am willing to accept job rotation now. (JRA) & $0.52^{* *}$ & 0.73 & & \\
\hline & 4. Before job rotation, the organization seeks my consent. (JRC) & $0.78 * *$ & 0.39 & & \\
\hline & 5. I believe job rotation is an excellent system. (JRS) & $0.64 * *$ & 0.59 & & \\
\hline & 6. Overall, I like job rotation. (JRL) & $0.76 * *$ & 0.42 & & \\
\hline \multirow[t]{12}{*}{ Role Stress } & Role Ambiguity (RA) & & & 0.78 & 0.75 \\
\hline & I. I do now know how to utilize my time appropriately. & $0.77^{* *}$ & 0.41 & & \\
\hline & 2. I have no idea of what I have to do every day. & $0.80 * *$ & 0.36 & & \\
\hline & 3. I have no clue of what the hospital's expectations of my job are. & $0.83 * *$ & 0.31 & & \\
\hline & Role Conflict (RC) & & & 0.72 & 0.71 \\
\hline & 4. Others often have inconsistent requirements for my job. & $0.69 * *$ & 0.52 & & \\
\hline & 5. I often did some unnecessary work. & $0.72^{* *}$ & 0.48 & & \\
\hline & $\begin{array}{l}\text { 6. Sometimes the tasks the hospital assigned to me were too } \\
\text { difficult or too complicated. }\end{array}$ & $0.76 * *$ & 0.42 & & \\
\hline & Role Overload (RO) & & & 0.81 & 0.76 \\
\hline & 7. My everyday workload is too much for me to finish. & $0.82^{* *}$ & 0.33 & & \\
\hline & 8. My assignments seem to become more and more complicated. & $0.8 I^{* *}$ & 0.34 & & \\
\hline & $\begin{array}{l}\text { 9. I am in charge of many duties and tasks at the same time, which } \\
\text { are too much for me to handle. }\end{array}$ & $0.78 * *$ & 0.39 & & \\
\hline \multirow[t]{12}{*}{ Job Satisfaction } & Internal Satisfaction (IS) & & & 0.86 & 0.77 \\
\hline & I. My job provides me the chance to fulfill my ability. & $0.79 * *$ & 0.37 & & \\
\hline & 2. I can derive a sense of achievement from my job. & $0.82^{* *}$ & 0.32 & & \\
\hline & 3. I am satisfied with my self-development from my job. & $0.86 * *$ & 0.27 & & \\
\hline & 4. I am competent to do my present job. & $0.91 * *$ & 0.18 & & \\
\hline & 5. I find my job meaningful. & $0.79 * *$ & 0.37 & & \\
\hline & External Satisfaction (ES) & & & 0.85 & 0.79 \\
\hline & 6. I am satisfied with my present job's environment and facilities. & $0.79 * *$ & 0.38 & & \\
\hline & $\begin{array}{l}\text { 7. Compared with other nursing personnel, I am content with my } \\
\text { salary. }\end{array}$ & $0.84 * *$ & 0.29 & & \\
\hline & 8. My present job provides me a chance for promotion. & $0.87^{* *}$ & 0.25 & & \\
\hline & 9. I get along well with my colleagues. & $0.74 * *$ & 0.45 & & \\
\hline & I0. I would get complimented when I do well on my job. & $0.78^{* *}$ & 0.39 & & \\
\hline \multirow{15}{*}{$\begin{array}{l}\text { Organizational } \\
\text { Commitment }\end{array}$} & Value Commitment (VC) & & & 0.79 & 0.79 \\
\hline & I. I have a strong sense of belonging to the hospital. & $0.58^{* *}$ & 0.53 & & \\
\hline & 2. I am willing to serve this hospital. & $0.7 I^{* *}$ & 0.49 & & \\
\hline & 3. I am proud to be a part of this hospital. & $0.8 I^{* *}$ & 0.34 & & \\
\hline & 4. I care about the future development of the hospital. & $0.70 * *$ & 0.51 & & \\
\hline & Effort Commitment (EC) & & & 0.80 & 0.77 \\
\hline & 5. I am willing to put extra effort to achieve the goals of my job. & $0.82 * *$ & 0.33 & & \\
\hline & 6. I try my best to overcome the difficulties of my job. & $0.84 * *$ & 0.29 & & \\
\hline & 7. I am willing to pass on my working experience to new staff. & $0.55^{* *}$ & 0.56 & & \\
\hline & 8. I actively help my colleagues to solve problems in their work. & $0.7 I^{* *}$ & 0.49 & & \\
\hline & Retention Commitment (RC) & & & 0.78 & 0.75 \\
\hline & 9. I feel I will have a promising future if I stay in this hospital. & $0.58^{* *}$ & 0.54 & & \\
\hline & 10. I have a profound attachment to this hospital. & $0.64 * *$ & 0.59 & & \\
\hline & $\begin{array}{l}\text { II. With the present working environment and system, I am willing } \\
\text { to stay in this hospital. }\end{array}$ & $0.48 * *$ & 0.77 & & \\
\hline & I2. If I leave this hospital, I will have guilt feelings. & $0.8 I^{* *}$ & 0.35 & & \\
\hline
\end{tabular}


Table 5: Descriptive Statistics of Sample ( $N=532)$

\begin{tabular}{|c|c|c|}
\hline Variable/ltem & Frequency & Percentage \\
\hline \multicolumn{3}{|l|}{ Hospitals } \\
\hline Medical Center A & 273 & 51.3 \\
\hline Medical Center B & 259 & 48.7 \\
\hline \multicolumn{3}{|l|}{ Gender } \\
\hline Female & 532 & 100 \\
\hline \multicolumn{3}{|l|}{ Age } \\
\hline 30 or under & 256 & 48.1 \\
\hline $31-40$ & 210 & 39.5 \\
\hline $4 I-50$ & 66 & 12.4 \\
\hline \multicolumn{3}{|l|}{ Marital status } \\
\hline Married & 225 & 42.3 \\
\hline Not married & 307 & 57.7 \\
\hline \multicolumn{3}{|l|}{ Education } \\
\hline College or under & 235 & 44.2 \\
\hline Bachelor & 226 & 42.5 \\
\hline Master or above & 71 & 13.3 \\
\hline \multicolumn{3}{|l|}{ Seniority } \\
\hline Less than 3 years & 92 & 17.3 \\
\hline $3-6$ years & 161 & 30.3 \\
\hline $6-10$ years & 149 & 28.0 \\
\hline 10 years or above & 130 & 24.4 \\
\hline \multicolumn{3}{|l|}{ Units } \\
\hline Ward & 270 & 50.8 \\
\hline Intensive care unit & 142 & 26.7 \\
\hline Others & 120 & 22.5 \\
\hline \multicolumn{3}{|l|}{ Job title } \\
\hline Nurse & 499 & 93.8 \\
\hline Head nurse & 33 & 6.2 \\
\hline
\end{tabular}

Note. ${ }^{*} \mathrm{p}<.0 \mathrm{I}, \mathrm{AVE}=$ Average variance extracted.

mote the benefits of job rotation to both individuals and the hospital while implementing job rotation periodically and fairly. The ultimate goal is to increase nurses' job satisfaction and encourage them to stay at their work. This would avoid the vicious circle of high turnover which is wasteful of the organization's valuable human resources.

The findings of this study reveal that role stress among nurses exercises negative influences on both job satisfaction and organizational commitment. The parameter estimates of the correlation show that the negative influence that role stress among nurses has on organizational commitment $(-0.79)$ is greater than that on job satisfaction (0.52 ). Therefore, when a medical organization attempts to enhance nurses' commitment to the organization, the findings suggest that reduction of role ambiguity (with a path coefficient of 0.82) in role stress has the best effect on enhancing nurses' organizational commitment.

Avian Influenza (AI) has caused hundreds of deaths in Europe. The hospital system of Taiwan, standing in the first line of prevention and treatment, has to effectively employ the experience of SARS in order to tackle the new serious challenge of AI. Though Taiwan is not an epidemic

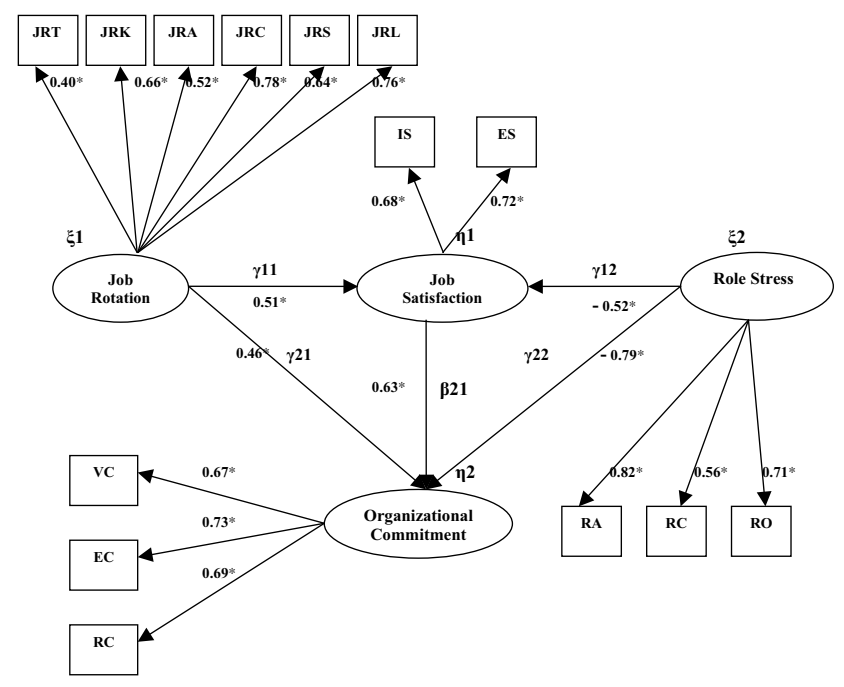

Figure 2

Structural Equation Modeling (SEM) of the relationship among job rotation, job satisfaction, organizational commitment, and role stress. (Note. * represents $\mathrm{p}<.0 \mathrm{I})$

area of AI, it is important for us to be well prepared to confront it, given that prevention is more important than treatment. It is essential that we try our best to build up an efficiently preventive system for AI and other serious infectious diseases. This study aims to investigate what is most important and critical in the preventive system. More specifically, what are the priorities in such a preventive system, especially under a limited condition of budgets and human resources?

\section{Research Limitations}

The findings of this study should be considered in view of the following limitations.

1. This study merely investigated the correlation between perception of job rotation, role stress, job satisfaction, and organizational commitment in a population of nurses. Factors influencing organizational commitment such as the nature of employment, work environment, work experience and management style, await further study.

Table 6: Model Fit Goodness of the Structural Equation Modeling

\begin{tabular}{lccccc}
\hline Fitness Statistics & $\chi^{2 / d f .}$ & GFI & AGFI & NFI & RMSR \\
\hline Standard Value & $<3$ & $>.9$ & $>.8$ & $>.9$ & $<.08$ \\
Conceptual Model & $\mathbf{2 . 1 5}$ & $\mathbf{0 . 9 3}$ & $\mathbf{0 . 8 9}$ & $\mathbf{0 . 9 1}$ & $\mathbf{0 . 0 2 6}$ \\
\hline
\end{tabular}

Note. $\chi^{2} / \mathrm{df} .=$ Ratio of Chi-square, GFI $=$ Goodness of Fit Index, AGFI = Adjusted GFI, NFI = Normal Fit Index, RMSR = Root Mean Square of Standardized Residual. 
2. This study examined a population of nurses in a single country and should be generalized cautiously to other populations. However, given the context of the study, the survey results exhibited adequate validity and reliability.

3. The primary research instrument in the study was the questionnaire, which has a certain degree of validity and reliability. However, the results of the voluntary survey would have been subject to numerous factors which could cause variations in the results, such as defensiveness, pretending, personal emotion and other attitudes.

4. This study examined only one time period, which would not reveal factors which have long-term effects. A multiple time period approach is suggested for follow-up study. Analyzing multiple periods of data would achieve more complete and objective statistical data.

\section{Competing interests}

The authors declare that they have no competing interests.

\section{Authors' contributions}

The following indicated the contributions of each author in this study: WHH conceived of the study, and participated in its design and coordination; CSC participated in the design of the study and performed the statistical analysis \& FG, conceived of the study, and participated in its design and coordination; YLS conceived of the study, and participated in its design and coordination; and RDL conceived of the study, and participated in its design and coordination. All authors read and approved the final manuscript.

\section{References}

I. Davis K, Jorgensen M: Ergonomics-pros and cons of job rotation as a means of reducing injury costs. J Occup Environ Hyg 2005, 2(I): I-3.

2. Hall D, Isabella L: Downward movement and career development. Organizational Dynamics 1985, 14:5-23.

3. Jaturanonda C, Nanthavanii S, Chongphaisal P: A survey study on weights of decision criteria for job rotation in Thailand: Comparison between public and private sectors. International Journal of Human Resource Management 2006, 17:1834-|85I.

4. Hsieh PC, Su HF: Retention and attrition of certified care assistants in the long-term care industry from the Taipe area: An interview survey. International Journal of Nursing Studies 2007, 44:93-104.

5. Sveinsdottir H, Biering P, Ramel A: Occupational stress, job satisfaction, and working environment Icelandic nurses: A crosssectional questionnaire survey. International Journal of Nursing Studies 2006, 43:875-889.

6. Zeithaml VA, Bitner MJ: Services marketing 7th edition. New York, McGraw-Hill; 2000.

7. Bernstein SL: Internal marketing of an ED-based public health initiative. American Journal of Emergency Medicine 2005, 23:4II-4I 3.

8. Watson PG, Marshall DR, Sexton KH: Improving perceptions of patient care - A nursing education and nursing practice initiative. Journal of Professional Nursing 2006, 22:280-288.

9. Seibert SE, Kraimer ML, Liden RC: A social capital theory of career success. Academy of Management Journal 200I, 44:2I 9-237.

10. Jorgensen M, Davis K, Kotowski S, Aedla P, Dunning K: Characteristics of job rotation in the midwest US manufacturing sector. Ergonomics 2005, 48:172I-1733.
II. Triggs DD, King PM: Job rotation. Professional Safety 2000, 45:32-34.

12. Campion MA, Cheraskin L, Steven MJ: Career-related antecedents and outcomes of job rotation. Academy of Management Journal 1994, 37:1518-1542.

13. Van Sell M, Brief AP, Schuler RS: Role conflict and role ambiguity: Integration of the literature and directions for future research. Human Relations 1981, 34:43-71.

14. Kahn RL, Wolfe DM, Quinn RP, Snoek JD, Rosenthal RA: Organizational stress: Studies in role conflict and ambiguity New York, John Wiley; 1964.

15. Piko BF: Burnout, role conflict, job satisfaction and psychosocial health among Hungarian health care staff: A questionnaire survey. International Journal of Nursing Studies 2006, 43:3II-3I8.

16. Bernard A, Whitaker M, Ray M, Rockich A, Barton-Baxter M, Barnes SL, Boulanger B, Tsuei B, Kearney P: Impact of language barrier on acute care medical professionals is dependent upon role. Journal of Professional Nursing 2006, 22:355-358.

17. Suzuki E, Itomine I, Kanoya Y, Katsuki T, Horii S, Sato C: Factors affecting rapid turnover of novice nurses in university hospitals. Journal of Occupational Health 2006, 48:49-61.

18. Disch J, Edwardson S, Adwan J: Nursing faculty satisfaction with individual, institutional, and leadership factors. Journal of Professional Nursing 2004, 20:323-332.

19. Melnyk BM: The latest evidence on factors impacting nurse retention and job satisfaction. Worldviews on Evidence-Based Nursing 2006, 3:20I-204.

20. Castle NG, Engberg J, Anderson RA: Job satisfaction of nursing home administrators and turnover. Medical Care Research and Review 2007, 64:|9|-2।I.

21. Porter LW, Lawer RE: Organizational, work, and personal factors in employee turnover and absenteeism. Psychological Bulletin 1973, 88: I5I-176.

22. Judge TA, Timothy A, Joyce EB: Relationship of core self-evaluation-self-esteem, generalized self-efficacy, locus of control, and emotional stability - with Job satisfaction and job performance: A meta-analysis. Journal of Applied Psychology 200I, 86:80-92.

23. Best ME, Thurston NE: Measuring nurse job satisfaction. Journal of Nursing Administration 2004, 34:283-290.

24. Jalonen P, Virtanen M, Vahtera J, Elovainio M, Kivimaki M: Predictors of sustained organizational commitment among nurses with temporary job contracts. Journal of Nursing Administration 2006 , 36:268-276.

25. Wagner CM: Organizational commitment as a predictor variable in nursing turnover research: literature review. Journal of Advanced Nursing 2007, 60:235-247.

26. Dee JR, Henkin $A B$, Singleton $C A$ : Organizational commitment of teachers in urban schools: Examining the effects of team structures. Urban Education 2006, 41:603-627.

27. Moss SA, McFarland J, Ngu S, Kijowska A: Maintaining an open mind to closed individuals: The effect of resource availability and leadership style on the association between openness to experience and organizational commitment. Journal of Research in Personality 2007, 41:259-275.

28. Porter LW, Steer RM, Mowday RT, Boulian PV: Organizational commitment, job satisfaction, and turnover among psychiatric technicians. Journal of Applied Psychology 1974, 59:603-609.

29. Trimble DE: Organizational commitment, job satisfaction, and turnover intention of missionaries. Journal of Psychology and Theology 2006, 34:349-360.

30. Arena MJ: Changing the way we change. Organizational Development Journal 2002, 20:33-47.

31. Erdheim J, Wang M, Zickar MJ: Linking the big five personality constructs to organizational commitment. Personality and Individual Differences 2006, 41:959-970.

32. Hrebiniak LG, Alutto JA: Personal and related factor, in the development of organizational commitment. Administrative Science Quarterly 1972, 17:559-560.

33. Lambert EG, Pasupuleti S, Cluse-Tolar T, Jennings M, Baker D: The impact of work-family conflict on social work and human service worker job satisfaction and organizational commitment: An exploratory study. Administration in Social Work 2006, 30:55-74. 
34. Farrell D, Rusbult CE: Exchange variables as predictors of job satisfaction, job commitment and turnover: The impact of rewards, costs, alternatives and investment. Organizational Behavior and Human Performance 198I, 27:78-95.

35. Lu KY, Chang LC, Wu HL: Relationships between professional commitment, job satisfaction, and work stress in public health nurses in Taiwan. Journal of Professional Nursing 2007, 23:110-116.

36. Tourangeau AE, Cranley LA: Nurse intention to remain employed: understanding and strengthening determinants. Journal of Advanced Nursing 2006, 55:497-509.

37. Kudo Y, Satoh T, Hosoi K, Miki T, Watanabe M, Kido S, Aizawa Y: Association between intention to stay on the job and job satisfaction among Japanese nurses in small and medium-sized private hospitals. Journal of Occupational Health 2006, 48:504-5I3.

38. Shimizu T, Eto R, Horiguchi I, Obata Y, Feng QL, Nagata S: Relationship between turnover and periodic health check-up data among Japanese hospital nurses: A three-year follow-up study. Journal of Occupational Health 2005, 47:327-333.

39. Haut ER, Sicoutris CP, Meredith DM, Sonnad SS, Reilly PM, Schwab $\mathrm{CW}$, Hanson CW, Gracias VH: Improved nurse job satisfaction and job retention with the transition from a mandatory consultation model to a semiclosed surgical intensive care unit: A I-year prospective evaluation. Critical Care Medicine 2006, 34:387-395.

40. Anil A, Brian M: Using job rotation to extract employee information. The Journal of Law, Economics, and Organization 2004, 20:400-4I5.

41. Shiao JSC, Koh D, Lo LH, Lim MK, Guo YLL: Factors predicting nurses' consideration of leaving their job during the SARS outbreak. Nursing Ethics 2007, 14:5-17.

42. Chen YM, Chen SH, Tsai CY, Lo LY: Role stress and job satisfaction for nurse specialists. Journal of Advanced Nursing 2007 59:497-509.

43. Hair JF, Anderson RE, Tatham RL, Black WC: Multivariate data analysis with reading London, Prentice Hall; 1998.

44. Nunnally JC: Psychometric theory 2nd edition. New York, McGraw-Hill; 1978.

45. Bagozzi RP, Yi Y: On the evaluation for structural equation models. Journal of the Academy of Marketing Science 1988, 16:74-94.

46. Joreskog KG, Sorbom D: LISREL 7 user's reference guide Mooresville, Scientific Software; 1989.

47. Brown SP, Peterson RA: Antecedents and consequences of salesperson job satisfaction: Meta-analysis and assessment of causal effects. Journal of Marketing Research 1993, 30:63-77.

48. Boshoff C, Mels G: A causal model to evaluate the relationships among supervision, role stress, organizational commitment and internal service quality. European Journal of marketing 1995, 29:23-42.

49. Beehr TA, Newman JE: Job stress, employee health and organizational effectiveness: $A$ fact analysis, model, and literature review. Personnel Psychology 1978, 31:665-669.

50. Chang CS, Weng $\mathrm{HC}$, Chang $\mathrm{HH}$, Hsu TH: Customer satisfaction in medical service encounter: A comparison between obstetrics and gynecology patients and general medical patients. Journal of Nursing Research 2006, 14:9-23.

5I. Fisher CD, Gitelson R: A meta-analysis of correlates of role conflict and ambiguity. Journal of Applied Psychology 1983, 168:320-333.

\section{Pre-publication history}

The pre-publication history for this paper can be accessed here:

http://www.biomedcentral.com/1472-6963/9/8/prepub
Publish with Bio Med Central and every scientist can read your work free of charge

"BioMed Central will be the most significant development for disseminating the results of biomedical research in our lifetime. "

Sir Paul Nurse, Cancer Research UK

Your research papers will be:

- available free of charge to the entire biomedical community

- peer reviewed and published immediately upon acceptance

- cited in PubMed and archived on PubMed Central

- yours - you keep the copyright
BioMedcentral 